\title{
Necessity of Restructuring the China-Africa Education Cooperation to Leverage the Fastest-Growing Economic Ties
}

\author{
TALING TENE RODRIGUE（大灵・德内•罗德里格） \\ $\mathrm{PhD}$. from Cameroon is a Research Fellow at the Institute of African Studies, Zhejiang Normal University \\ (China) \\ Vice-Director of the Center for Francophone Studies, Institute of African Studies, Zhejiang Normal University. \\ 688 Yingbin road Jinhua Zhejiang, China; Zip: 321004
}

\begin{abstract}
:
Study Focus: This article put forward the necessity of rebalancing the China-Africa Fastest-Growing Economic Ties with a Leveraged Education Cooperation as well as the necessity of restructuring the actual patterns of ChinaAfrica Education Cooperation.

Methodology: The content of this paper relies on written documents (including books, scientific journals, articles, and official reports) from primary and secondary sources most of which are available online as well as on the author's teaching experience in Chinese and African Universities.

Findings:

1) "Business" but not "Education" remains the top driver of the China-Africa cooperation. Therefore, it is noteworthy questioning the share of fundamental areas of cooperation such as Education and Culture that should pioneer and propel sustainable partnerships.

2) African countries seem disadvantaged in the actual patterns of China-Africa Education Cooperation. There is a need to restructure the cooperation on education and improve the overall image of China and Africa Cooperation. 3) The Chinese Study of Africa and the African Study of China are not contemporary stories, but a continuous course of very old history that can be traced back before the Christian era and should be further promoted in today's modern academia.

4) From a theoretical basis to a scientific methodology, from institutionalized frameworks to government policies, an epistemic assessment of China by the African academic circles is of urgent need. The African scholarship should have its de-westernized appraisal of China and vice-versa.

5) Up to now, there is no genuine African Sinology in African academic curriculums. A sort of Africa-centered study of China that fulfills traditional discipline criteria must be put in place in today's African Academia.

Conclusion \& Suggestions:

In brief, there is a real necessity of rebalancing the China-Africa fastest-growing economic ties with leveraged education cooperation and reforms. It is for Chinese and African scholars a sole duty to brainstorm new patterns of cooperation, and so paves new ways for an in-depth study and understanding of China and Africa. Moreover, a genuine African Sinology that uses a socio-scientific methodology to critically examine and investigate China, understands the Chinese spirit by all means and draw the benefits for the interests of African people must take place in African education curriculums. For that purpose, the present article proposes the terminology "Afrisinology" as a new paradigm to approach the African Study of China in African academia.
\end{abstract}

Keywords: African Studies, Sinology, "Afrisinology”, China-Africa Education Cooperation.

DOI: $10.7176 / \mathrm{JAAS} / 62-03$

Publication date:March $31^{\text {st }} 2020$

\section{1-Introduction}

International cooperation between nations enhances ties and paves ways for sustainable development. Education as the process of facilitating learning, acquisition of knowledge, skills, values, beliefs, habits and most importantly acquiring the technological know-how essential for African countries to be able to achieve high levels of economic growth, should be at the frontline of China-Africa cooperation. However, the China-Africa Cooperation has been portrayed as an economic one as exchanges of people and goods are mainly driven by business motives, with the tremendous increase in China-Africa trade volume and exponential Chinese investment in Africa the past few decades. Heavily relying on their natural resources and raw materials in exchange for manufactured products and further investments, African countries seem to be disadvantaged in the actual China-Africa Cooperation patterns. Nevertheless, a lot of efforts have been deployed to deal with these shortcomings with the creation of the Forum on China-Africa Cooperation (FOCAC) since the year 2000 in which numerous pledges on Education Cooperation between China and African countries have been made. But most of these pledges have been criticized for not being effective and efficient enough as many of them were announced at a Pan African level, but not allocated at the fora to specific African countries. Added to the fact that these pledges wherein majority oriented to African countries which have signed the Belt and Road Initiative (BRI) with China (King, 2019).Moreover, Chinese Academia in recent years has devoted unprecedented efforts in research and study of Africa, with the booming of funded 
research centers, specialized institutions and an increasing number of Chinese scholars exerting field works investigations on the continent. These moves, unfortunately, are not balanced with equal involvement of African governments and scholars in the research and study of China for the benefits of African countries. As a result, there is unbalanced cooperation on education between China and African countries that cannot leverage the fastest growing economic ties. Therefore, there is an urgent need to restructure the China-Africa Education Cooperation, rebalance the Chinese study of Africa and deepen the African Study of China. A genuine African Sinology or "Afrisinology" has to be initiated in African Academic circles.

\section{2- Necessity of Rebalancing the China-Africa Fastest Growing Economic Ties with Leveraged Education cooperation \\ 2.1 Economic Ties should be grounded on Strong Education Cooperation}

Long considered as third world countries, China and African countries have been at the margin of the world economic, cultural and knowledge sharing spotlights. However, China's economy has grown tremendously in the past three decades to become the world's second-largest economy after the United States of America and the biggest developing country in the world. Meanwhile, the African continent has become the hope of world economic growth with the highest number of developing countries concentrated on the continent. For several reasons, China has gradually come into a strategic partnership with African countries, leading to an unprecedented need for mutual understanding, especially the understanding of Africa by the Chinese leadership under the pressing need to keep up with China's opening-up policies and growing global status. Since 2000, the Forum on ChinaAfrica Cooperation (FOCAC) has increasingly become the major platform of dialogue and concertation between China and African countries. Nowadays, China has become by far Africa's biggest trading partner, China and Africa are exchanging more than $\$ 200$ billion worth of goods year in year out; According to statistics from the General Administration of Customs of China, in 2018, China's total import and export volume with Africa was the US \$204.19 billion, a year-on-year increase of 19.7\%, exceeding the overall growth rate of foreign trade in the same period by 7.1 percentage points. In 2018, the growth rate of China's trade with Africa was the highest in the world. (Source: Ministry of Commerce People's Republic of China) However, some scholars believe that this fastest economic cooperation is not keeping in line with appropriate education cooperation so that to ensure sustainable cooperation. Mulinda, for example, believes that "the Cooperation between China and African countries has often been portrayed as an economic one..." and that "not much is written about the knowledge production interaction between both China and African countries" (Mulinda, 2015). At the people-to-people level, they have been dynamic exchanges yet plugged as well by irregularities. According to the Chinese newspaper China Daily (Suzhou, 2017), the number of Chinese immigrants in Africa has risen sevenfold over less than two decades. The Annual Report on Overseas Chinese Study conducted by researchers at Huaqiao, Peking and Xiamen universities, and released by the Social Sciences Academic Press, a publisher affiliated with the Chinese Academy of Social Sciences said the African continent was home to more than 1.1 million Chinese immigrants in 2012, compared with less than 160,000 in 1996. When it comes to the qualities and skills of these immigrants, the Peking University's School of International Studies Prof. Li Anshan acknowledges that "the first Chinese immigrants in Africa were laborers working in retail or catering. But in recent years, more Chinese intellectuals and skilled professionals have moved to Africa". Up to now, more than 1.5 million Chinese people are estimated to be living and working in Africa, most of them traders in search of new business opportunities. Meanwhile, statistics about Africans living in China remain unclear; some estimation puts the number at around 30 thousand. The CNN reporter Jenni Marsh in an article titled "The African migrants giving up on the Chinese dream" already noticed that there was an estimation of more than 100,000 Africans living in the city of Guangzhou alone (Jenni Marsh, 2016). According to official figures, 430,000 arrivals and exits by nationals from African countries were recorded at the city's checkpoints in the first nine months of 2014. Among them, there were 16,000 Africans including North Africans residing in Guangzhou (Zhuang Pinghui, 2014). Of these residents, 4,000 were long term residents, who are defined by city officials as living for longer than 6 months in the city, most of them businesspeople in search of better opportunities. In a word, business but neither education nor culture remains the top driver of the China-Africa people-to-people exchanges. Therefore, it is noteworthy questioning the share of fundamental areas of cooperation such as Education and Culture that should pioneer and prop up sustainable partnerships. In brief, there is a real necessity of rebalancing the China-Africa fastest-growing economic ties with leveraged education cooperation and reform.

\subsection{Necessity of restructuring the China-Africa Education Cooperation}

It is believed by many (Cambridge, James; Thompson, 2004; Hayden, Mary; McIntosh, 2018) that the benefits of international cooperation are reflected in mainly three gradual levels: Individual-level, Institutional level and Governmental level. Mvuh \& Liu worked on the case of China-Cameroon education cooperation and outlined the following benefits: "Scholarships", "Infrastructures building (Classrooms, training centers)", "cross-cultural experiences (of local students with the Chinese teachers)", "Job opportunities (translators, local Chinese teachers)" 
as well as "management policies sharing" on the Cameroonian side, while on the Chinese side "the Internationalization of China's Universities", "the extension of China's soft-power", "the improvement of National image", "the job opportunities for Chinese teachers and volunteers send in Africa", "the establishment of Confucius Institutes on the continent", etc.( Mvuh \& Liu,2019). In a word, China's main benefits are the internationalization of its education and the extension of China's soft-power in Africa. Some critics have voiced out concern on the internationalization of education saying that it leads to the erosion of local education systems and indigenous values and norms, which tend to be replaced with the internationalizing systems and cultural and ideological values and orientation (Vanessa, 2017). This case study is a typical pattern of the current China-Africa education cooperation that historically has been an important content of the FOCAC, and technically could be found under different labels such as "scholarships", "cultural partnerships", "mutual learning", "knowledge sharing", "research", "capacity building", "training opportunities", "people-to-people exchanges", etc. They have been promises of more support to African countries wishing to establish Confucius Institutes. Equally, at the university level, they have been financial encouragement to African universities to establish Chinese research centers and to Chinese universities to open more African research centers (KING, 2019). In a word China has been investing a lot in education cooperation with African countries, and the outcomes of that cooperation have been very pragmatic and tangible in some cases. Nevertheless, the pattern has been largely criticized by the western media and academic circles. Alden \& Large argue that, even though Education and Human Resources Development have been constant features of the FOCAC Action Plans, there has been relatively little academic research on these dimensions. For instance, in a recent volume on New Directions in Africa-China Studies, none of the 21 chapters examine the history or contemporary aspects of Africa-China studies in education (Alden \& Large, 2019). Moreover, FOCAC pledges have been criticized for being announced at a Pan African level, but not, at the fora, allocated to specific countries across the continent. Statistics also show that, a great deal of Chinese support in education cooperation is oriented to the most strategic BRI countries. Already in 2017, no less than $66 \%$ of all Chinese government scholarships were going to students in the BRI countries. It was noted besides that 153 Confucius Institutes were operating in 54 BRI countries. (King, 2019). The Confucius Institutes have been labeled by some as "Trojan horses" (Mosher, 2012). Already in 2009, James F. was claiming that the Confucius Institute project can be seen at one level as an attempt to increase Chinese language learning and an appreciation of Chinese culture, but at another level, it is part of a broader soft power projection in which China is attempting to win hearts and minds for political purposes. And that besides Confucius Institutes, some other ways China raises its cultural profile overseas include Chinese contemporary art exhibitions, television programs, concerts by popular singers, and translations of Chinese literature. (James F, 2009). According to Fabrice De Pierrebourg and Michel JuneauKatsuya, some individuals holding positions within the Confucius Institute system have backgrounds in Chinese security agencies and United Front Work Department, "which manages important dossiers concerning foreign countries. These include propaganda, the control of Chinese students abroad, the recruiting of agents among the Chinese diaspora (and among sympathetic foreigners), and long-term clandestine operations."( Fabrice\& Michel, 2009). The Chinese responses to these sharp accusations and criticisms have been straightforward. An article from the state-run China Daily outlined that "Confucius Institutes' work is misunderstood from time to time", citing the example of Mosher calling Confucius Institutes "Trojan Horses with Chinese characteristics." Another response from the director-general of the Hanban (headquarter of Confucius Institutes located in the Chinese capital Beijing), $\mathrm{Xu}$ Lin, emphasized that "The Confucius Institutes are not Trojan Horses since we are holding no weapons in our hands."'(Qu Yingpu, Zhao Huanxin \& Cheng Ying, 2012). The People's Daily, another Chinese state-run newspaper reported Osaka Sangyo University, which opened a Confucius Institute and closed it after one year of operation. The Japanese institution formally apologized for an employee who called the Confucius Institute "a spy agency established to gather cultural intelligence.”(Source: People's Daily, 12 June 2010). Confucius Institutes are frequently compared to cultural associations such as the UK's British Council (Jessica, 2007), Germany's Goethe-Institut (Justin, 2011), France's Alliance Française, Italy’s Società Dante Alighieri, and Spain's Instituto Cervantes (Alexander K. \& Ting Song, 2012). For instance, an editorial in the state-owned China Daily newspaper accused Confucius Institute opponents of double standards of not calling "Goethe-Institut, Alliance Française or Cervantes Institutes propaganda vehicles or tools of cultural invasion". The editorial noted that "China is not the first to set up such institutes nor does it have a monopoly over overseas cultural promotion." (Liu Chang, 2010) Steven Mosher notes: "Unlike Alliance Francaise, the Confucius Institutes are not independent of their government; unlike the Goethe-Institute establishments, they do not occupy their premises. Instead, participating universities agree to provide office space in exchange for funding, and to cede academic control to the United Front Work Department of the Chinese Communist Party."(Mosher, 2012) China is opening up and willing to embrace the world, making the utmost efforts to strengthen cooperation in all sectors. Africa is in great need of education development and is largely opening its arms to embrace cooperation with China. However, the controversies in the above few examples show that there is a necessity to restructure the actual patterns of education cooperation between China and African countries so that to ensure their sustainability and improve the overall image of both sides. It is for Chinese and African scholars a sole duty to brainstorm new patterns of cooperation 
and so to pave new ways for an in-depth study and understanding of China and Africa.

\section{Status quo of African Studies in China and Chinese Studies in Africa}

Africa is known to be the origin of Mankind, and together with China both are cradles of human civilizations with long histories and splendid cultures. The "Study" of each other can be traced back to a distant past as suggest records of early contact between China and Africa. In fact, there is a record of African Acrobats visiting China as early as at the 2nd Century B.C. while already in 1405-1433, the Ming dynasty, in the Chinese navigator Zheng He sailed westward through the Indian Ocean and beyond for seven times, out of which he reached the African coast four times. (Source: Assistant foreign minister of the People's Republic of China, Zhai Jun 2009). Even though ancient academic or intellectual exchanges between both sides are not clearly mapped out, still they are claims of earlier Chinese maps of Africa, far before the western exploration of the continent.

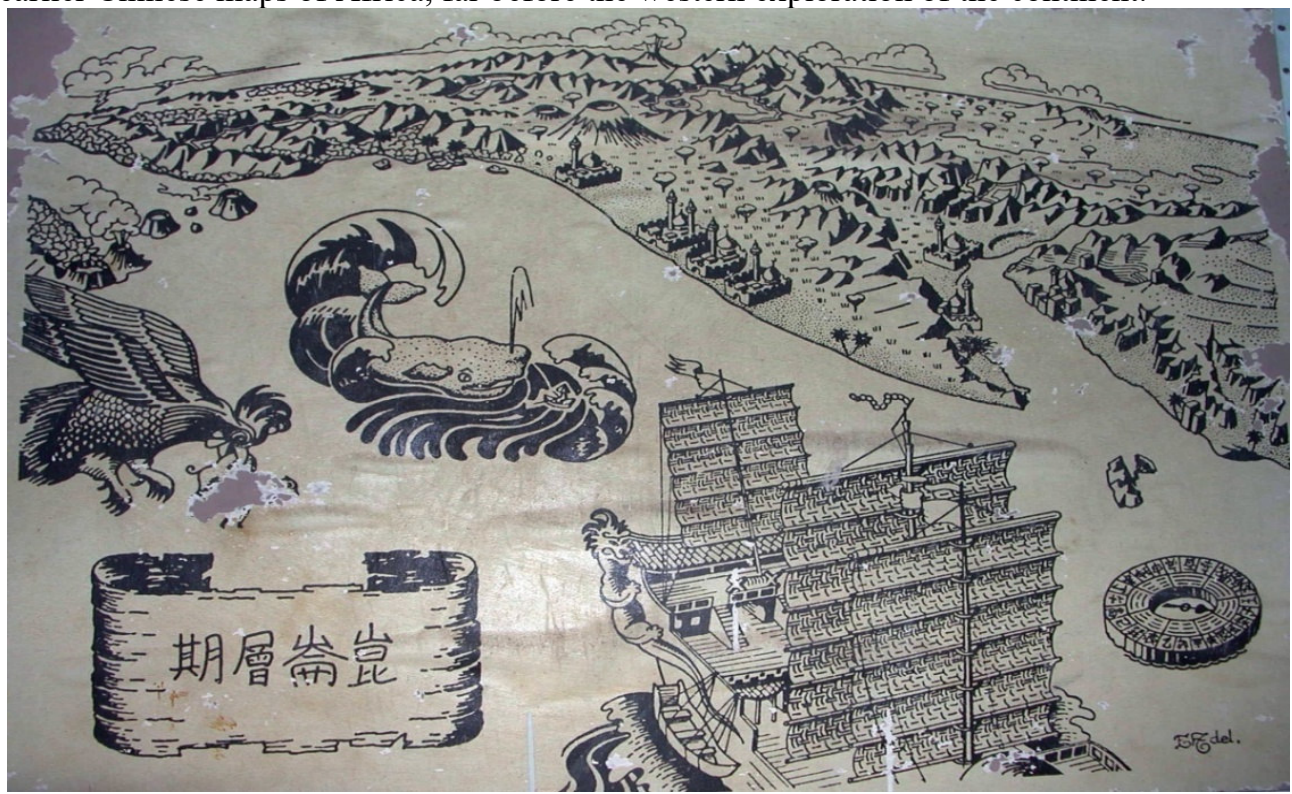

Figure1. Map of earliest Chinese Navigator Sailing the East African Waters

In brief, the Chinese Study of Africa and the African Study of China is not a contemporary story, but a continuous course of very old history that can be traced back before the Christian era. The foundation of New China in 1949 opened up a new era of China-Africa relations. In May 1956, China's establishments of diplomatic ties with Egypt opened up diplomatic relations between new China and African countries and pave the way to a new academic era of China-Africa Studies.

\subsection{Necessity to restructure the African Studies in China}

African Studies in contemporary China is merely a half-century story, period of human history that has been marked by western ideological domination in almost all parts of the world. The Colonial motives brought Europeans to a much larger, wider and deeper study of contemporary Africa as earlier as the 14th century. Moreover, the extended European imperialism in Asia, and most specifically in China the 18th Century have created an indirect connection between Africa and the East, and therefore influenced the study and knowledge of Africa by the Chinese. This indirect linkage has been the origin of distortions and bias plugging the knowledge content on Africa in the Chinese education curriculum. Professor Liu Hongwu, one of the leading Chinese Africanist, Changjiang Scholar of the Chinese Ministry of Education in his book $<$ African Studies from Chinese Perspective $>$ summed up the root problem of the African Studies in Chinese academia as follow: "After modern times, due to the gradual baptism of the western wind and the European civilization, Chinese people have gained a new dimension of world cognition, and their world outlook and self-knowledge have been broadened and changed. However, the western empire was so strong that China, which was relatively backward, tried to recognize the west in the process of saving the nation from extinction and translating western learning, thinking that the path of reform was to seek for strength. Over the past 100 years, Chinese people have made great achievements in learning from the west. This process of "learning from Europe and America" has itself become one of the reflections of the Renaissance and the rise of Chinese civilization. However, in this process, western civilization which was so strong was understood by the Chinese as a universal world civilization, and some Chinese took western civilization as the synonym of modern civilization Taking the scale of western civilization as the scale of all civilizations, the result is that Chinese people's world concept has unconsciously formed a 'Sino-Western dual dimension', and the 'opening-up' to the outside world has almost become 'opening-up to western civilization','. In many cases, what 
we call "Chinese and foreign civilizations" has become "Chinese and western civilizations". A comparative study of Chinese and foreign civilizations is actually a comparative study of Chinese and western civilizations (Liu Hongwu, 2019).It appears clear that there is an urgent necessity to restructure the African Studies in the Chinese academia so that to create more direct connection, a sort of full contact of the Chinese to the African experiences. At the same time these restructurings should create rooms for the Chinese roadmap of rejuvenation, therefore should take into account the Chinese characteristics of development so that to strengthen a better Chinese and African "community with shared future". The year 2000 was a turning moment for China to revitalized its policies for a better cognition of Africa with the launching of the FOCAC, a platform that has ever since its creation played an unprecedented role in speeding up the dialogues and concertation between leaders of China and African countries. Since then on, overwhelming policies and reform in China in favor of African Studies have been enacted. The most obvious is the booming of many African Institutes and Research Centers in Chinese universities. Among some of the most prominent ones are the Center for African Studies of Yunnan University (Since 1998, formerly established in 2007), Institute of African Studies, and Zhejiang Normal University (Since 2007). The China-African Institute is the last in date established under President Xi Jinping's important measures to strengthen China-Africa cooperation at the Beijing summit of the Forum on China-Africa Cooperation FOCAC 2018. On September 3, 2008 , in his speech at the opening ceremony of the Beijing summit of the FOCAC, President XiJinping proposed to focus on the implementation of the eight major initiatives on China-Africa Cooperation. It was therefore officially announced that China has decided to establish the Chinese academy of African Studies to deepen mutual learning among civilizations and Africa. The establishment of the Chinese Academy of African studies was listed as the first task of the people-to-people exchange initiative among the eight initiatives. The Chinese academy of social sciences was to be the sponsor of the China-African Institute. The aim of the China-African Institute is to deepen mutual learning with African countries, enhance exchanges of experience in governance and development, and provide intellectual and human resources support for China-Africa Cooperation in the "One Belt And One Road" initiative, the building of a future-oriented comprehensive strategic partnership of cooperation, and the building of a closer China-Africa community with a Shared Future. Relying on the strong research strength of the Chinese academy of social sciences and the sound foundation of cooperation with Africa, the China-African Institute will organize and carry out its work in a variety of ways and channels, presenting a work pattern integrating research, exchange, training and communication, and fully reflecting the characteristics of high-end, comprehensive, professional and sustainable work. The China-African Institute will support exchanges and cooperation between Chinese and African academics and think tanks in various forms, including joint research, academic visits, seminars and personnel training. On April 9, 2010, the inaugural meeting of the China-African Institute was held in Beijing. Yang Jiechi, the member of the political bureau of the CPC central committee and director of the office of the central foreign affairs commission, attended the congress. Chinese President Xi Jinping sent a congratulatory letter to the establishment of the China-African Institute. Representatives of Chinese and African government departments, academic institutions, think tanks, social celebrities and African nationals in China attended the conference along with 350 people(Source: People's Daily). Some of these prominent Chinese institutions have extended their branches in Africa or established a closer partnership with African Universities. The recruitment of African teachers and researchers in these Chinese institutions has also been on the rise. One of the most illustrative examples is the Institute of African Studies at Zhejiang Normal University where I am currently holding a position as Vice Director of the Center for Francophone Studies. The Institute Since its creation in 2007 has created a branch in South Africa, establish a partnership with several African Universities, recruited up to 8 African teachers from countries such as Nigeria, South Africa, Cameroon, Mali, Somalia, Mauritania, Burundi, lunched its own Journal of African Studies, establish its own and the African Museum in a Chinese University,.... The institute has gain recognition from African scholars and institutions, co-hosted several international fora in China and Africa, and been visited by more than a dozen of African ambassadors. It's one of the leading institutions of African Studies in Chinese academia and the unique one led by a Chinese scholar who has Studied Africa. This is perhaps one of the main reasons for the institutions' success, for there is no better way to understand Africa's reality than living in Africa and studying with Africans in African institutions. Professor Liu is among the first Chinese Africanist to acknowledge the problem of "Sino-western duality in Chinese academia" and to point out the necessity of de-westernizing the minds of the Chinese scholarship for a better study of Africa. This is a fundamental step to lay down a genuine curriculum of African Studies in Chinese academia. However, a lot remains to be done, for the mindsets of people will not easily change as long as international media discourses about Africa remain that of poverty, wars, and migration.

\subsection{Necessity of Restructuring the Chinese Studies in Africa}

There is no doubt that China is overwhelmingly embracing African countries in its opening up agenda. It suffices to follow the roadmap of official visits of top Chinese leaderships in African countries the last ten years to have a clear understanding, added to the number of Chinese people and businesses operating on the continent. On the other side, African countries driven by their own agendas (among others the UN 2030 Sustainable Development 
Agenda, AU Agenda 2063, and the development strategies of individual African countries...), seem to converge opinions in welcoming China's support and partnership. The $6^{\text {th }}$ edition of the FOCAC summit held in Beijing the September $4^{\text {th }}, 2018$, for example, gathered 40 African head of states around the same table with the Chinese leadership led by president Xi Jingping, under the witness eyes of the Secretary-General of the United Nations, its Excellency Mr. Antonio Guterres. In brief, there are shared interests and pledges in the ongoing China-Africa relationship. However, the lack of a deep study and proper understanding of China by African countries, may not help achieves some of the pledges or in the long-run compromise some African interests in the relation. It is a fact that today's Africans Education curriculums suffer from westernization even more than any other place in the world. As direct consequences of centuries of western indoctrination under colonial rule, Africans have gradually lost their own cultural identities and values. As a product of tailored western education, a great deal of today's African scholarship has come to accept the western world's views as universal. There is no denying that the actual scholastic discourses on China in Africa are hindered by western interferences from media coverage to politics and economy.

In this golden decade of opportunities, it is a great time for the African scholarship to have a much deeper study of China and demarcate their opinions and views on China from that of the West. These shifts in postures and attitudes should be operated at the individual level, at the institutional level and most importantly at the governmental level. At the individual level, for example, a de-westernization of the African scholarships' mind is a prior step that should be branded by the rebirth of the African identity and self-cognition, only then the African scholarship will embrace the world with a single a unique perspective that better serves the interest of Africa. At the institutional level, the creation of Chinese studies Centers led by African scholars in African Universities, the signing and implementation of MoU's between Chinese and African Universities as well as many cooperation fora on education and knowledge sharing among African and Chinese Universities over the continent should be considered. At the governmental level, more soft policies should be enacted to encourage African scholars' visits and research in China, more financial supports for research and student exchanges as well as specialized scholarships and training programs should be provided, but most importantly these research programs or scholarships should be followed up through diplomatic canals to make sure the target is reached and that the results benefit the country. In a word, Africans should be subjects and initiators of Chinese Studies and should carry them on in their own institutions to solve their most urgent Chinese related affairs, a sort of genuine African sinology or "Afrisinology".

Some slight efforts have been made at the institutional and governmental levels in some African countries to achieve the purpose of "Africa's study of China from an African perspective". And Chinese diplomacy seems to supports such efforts; I mean efforts that go far beyond the Confucius Institutes agenda of "Chinese language and culture's dissemination from the Chinese perspective".

Case of Egypt.

For instance, China and Egypt on April 24, 2005, signed an agreement on establishing the Egyptian Chinese University (ECU) in Cairo, the Egyptian capital. First, of its kind in Africa, The university was established by a presidential decree as a non-profit organization, offering a higher level of academic education in the fields of engineering, physical therapy, economics, international trade, pharmacy and medical technology in collaboration with top Chinese Universities such as Beijing Jiao Tong University, Liaoning University, Hubei University, North China Electric Power University.

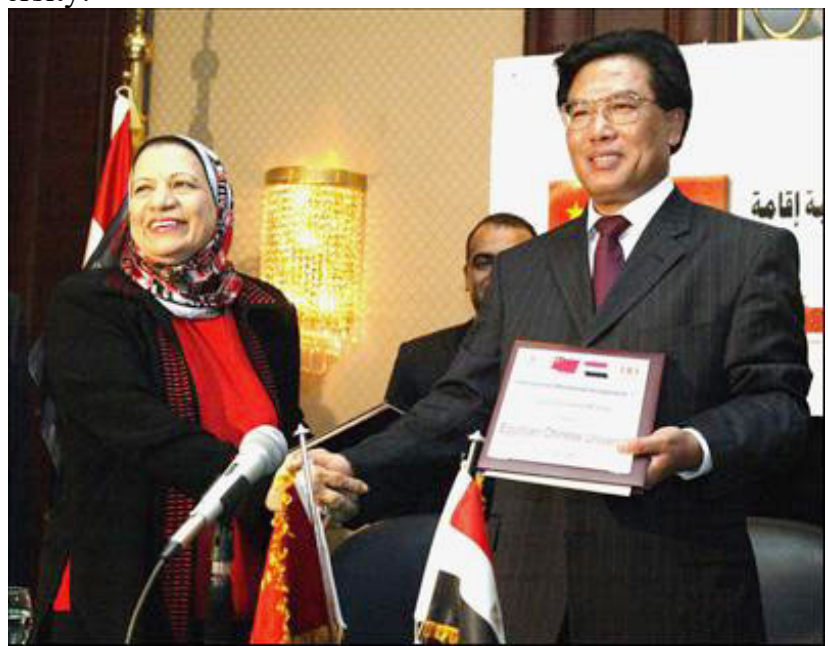

Figure2: The photo shows president of China's Liaoning University Cheng Wei (R) and Karima Abdullah Karim (L), the board chairwoman of Egypt's International Education Institution (IEI) at the signing ceremony( People's Daily April 26, 2005). 
It is to be noticed Egypt is the very first Africa country to sign diplomatic ties with the new China in 1957 , and one of the strategic country of the BRI initiative, and also that historically, the first Africans to set boots in China were Egyptian acrobats in 112 B.C. "Egypt has always been in the frontline of playing a leadership role on the Continent, and taking its responsibility as old Civilization”. Just as mentioned Ashraf el-Shihy, the ECU president in an interview with Xinhua News, a Chinese State-run journal, he further stressed that "China is not just a country, but it is a very big industrial and trade power. The ECU is a result of the natural approach between the oldest two civilizations in history: Egypt and China. (...) The ECU is the first and only one of its kind in the Middle East and Africa...The total number of ECU students so far is about 2,500. We care for providing highquality education than having a large number of students, which is why our classrooms are small but so many" said the ECU president and Egypt's former higher education minister Ashraf el-Shihy (Yurou, 2019).

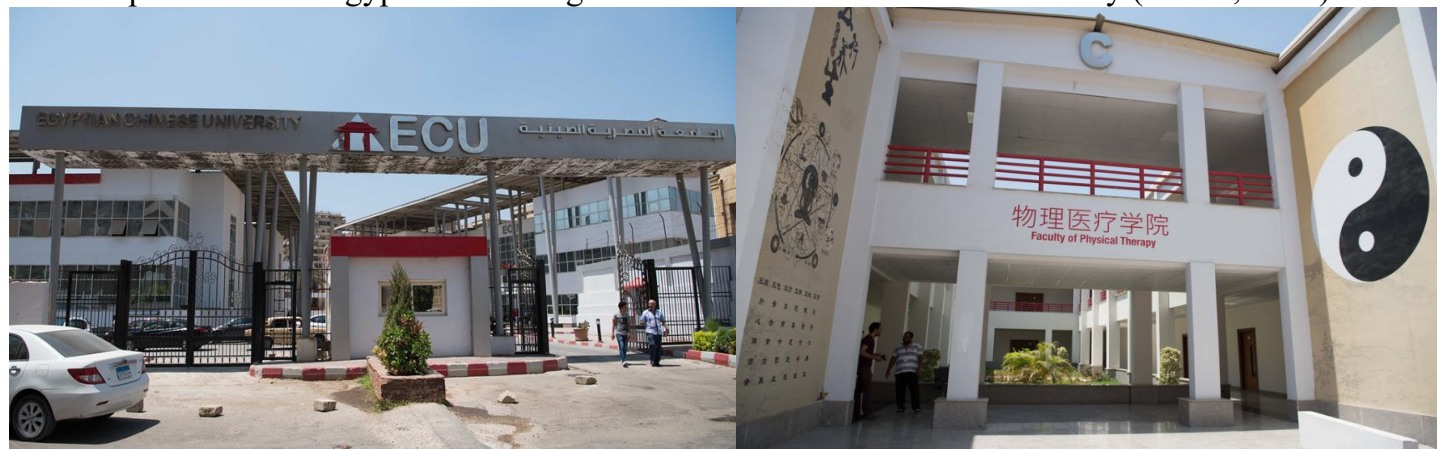

Case of Nigeria.

Figure3: Egyptian Chinese University (ECU)

The University Of Lagos (UNILAG), Akoka has unveiled the institute of Nigeria-China Development Studies (NCDS), a research institute established to inject new vitality into Nigeria-China development as well as collaboration in order to strengthen the relationship between both countries. The unveiling, which took place at the institution's senate chambers was followed by a signing of Memorandum of Understanding (MoU) between UNILAG and Chinese Investors Association for Development and Promotion (CIADP). Addressing reporters on the occasion of the unveiling of NCDS, the vice-chancellor, Prof Oluwatoyin Ogundipe said the institute was established to brace up with current trends in global affairs. Prof. Olufemi Saibu, Director of the Institute of Nigeria-China Development Studies, UNILAG, told the News Agency of Nigeria (NAN) in Lagos that Nigeria should also establish a similar center in China. According to him, there has been a lot of misunderstanding between Nigerians and Chinese due to lack of openness, issues of mindset and language inhibitions. We are working at how best to create more understanding between Nigerians and the Chinese. We want to trust the Chinese as much as we want the Chinese to trust us. (Maria Diamond, 2018)

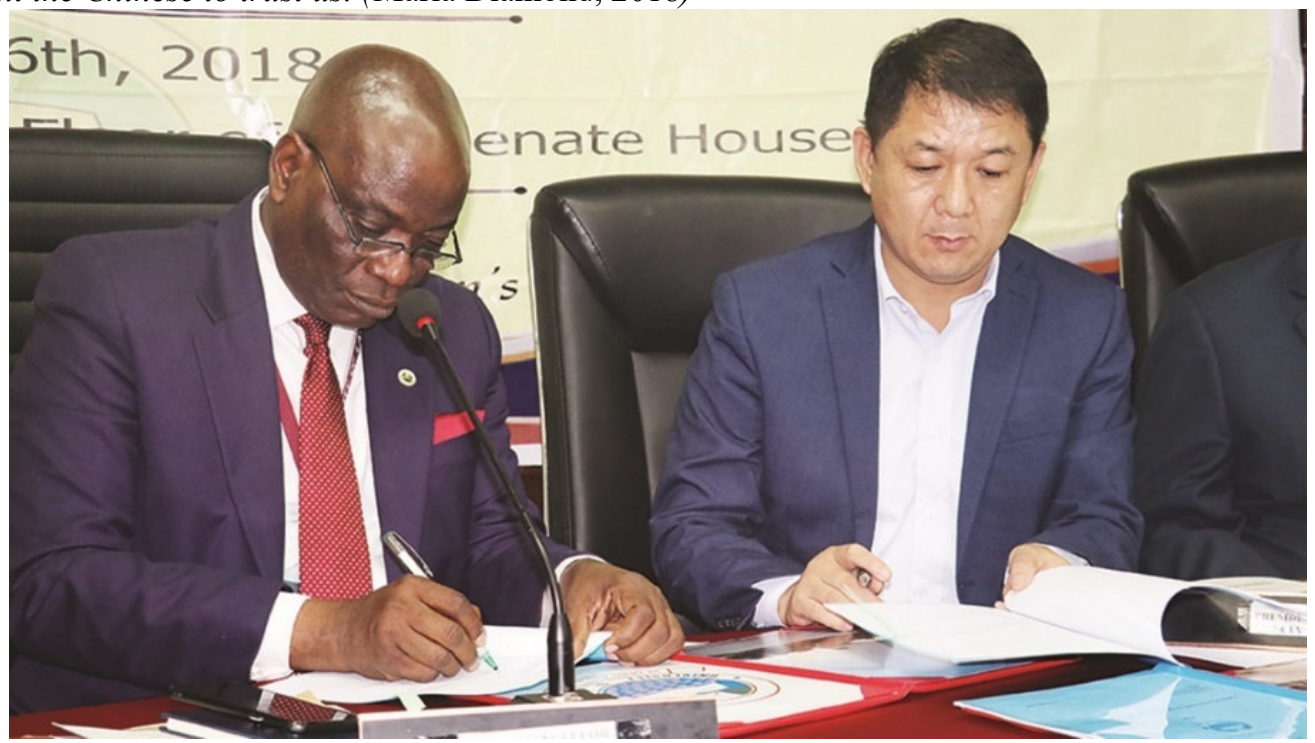

Figure4. Vice-Chancellor, University of Lagos, Prof. Oluwatoyin Ogundipe (left); and President, Chinese Investors Association for Development and Promotion; Ronnie Liu Changan at the signing of the Memorandum of Understanding (MoU) for University of Lagos Institute of Nigeria-China Development Studies.

Case of South Africa.

The Centre for Chinese Studies (CCS) at Stellenbosch University is the leading African research institution for 
innovative and policy relevant analysis of the relations between China and Africa. It promotes the exchange of knowledge, ideas and experiences between China and Africa. The first of its kind in South Africa, the CCS at Stellenbosch University housed in the Postgraduate and International Office. Despite having its own philosophy of analyzing the China-Africa cooperation, the Centre has maintains close ties to the Confucius Institute at Stellenbosch University, and has set up co-operative linkages with key universities and institutions in China, pursuing both research collaboration and academic exchanges, including the Shanghai Institutes for International Studies (SIIS), Shanghai, the Institute for African Studies at Zhejiang Normal University, Jinhua, the Institute of West Asian and African Studies (IWAAS), Chinese Academy of Social Sciences, Beijing.

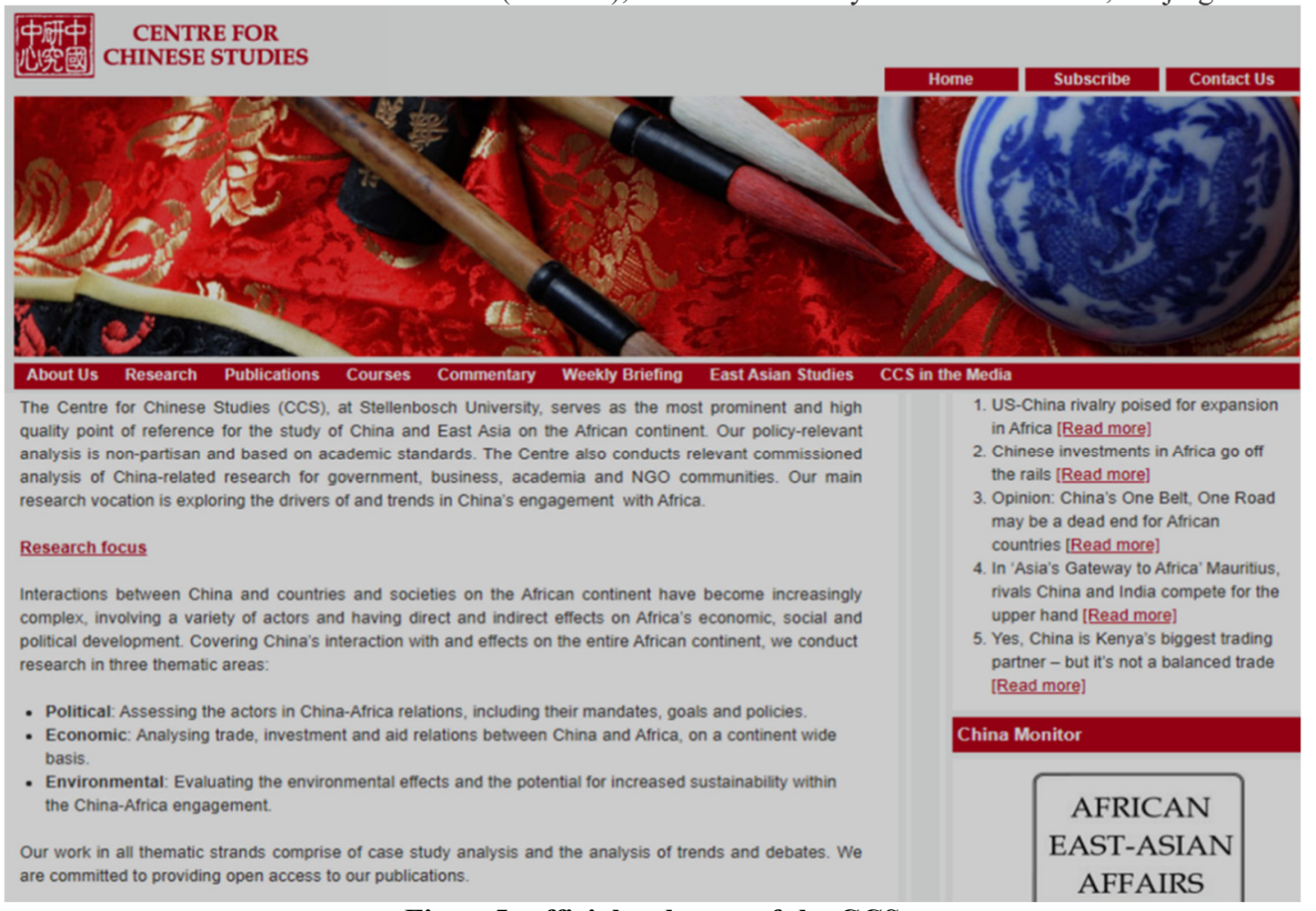

\section{Case of Tanzania.}

\section{Figure5: official webpage of the CCS}

In Dar Es Salaam (Tanzania), was launched the Center for Chinese Studies at the University of Dar Es Salaam by the Tanzanian Minister for Foreign Affairs and East African Cooperation, Augustine Mahiga. Inaugurating the Center at the University of Dar es Salaam, Mahiga said: "The Center for Chinese Studies will be a case study for Tanzanians to learn how China advanced from a poor country to an economic powerhouse". She added that the Center will also enable Tanzanians to conduct in-depth research on the relevance of China's development experience to the development of Tanzania and Africa in general. The Center for Chinese Studies in Tanzania was the third research institutes in Africa specialized in Chinese studies at the time of its inauguration after the Center for Chinese Studies at Stellenbosch University in South Africa and the Center for Chinese Studies in Nigeria. Wang Ke, the Chinese Ambassador to Tanzania stated at the opening ceremony that "To better understand China, you need to be objective and independent in thinking. Only in this way you can present a real China to the people in Tanzania and other African countries". "Development is the biggest challenge facing the world, and China's experience in development may be helpful to African countries," said the Chinese envoy. (Mu Xuequan, 2018). It is noteworthy that francophone African countries still lag behind, this is explained partly by the large influence of France on its ancient colonies but also by the lack of the political will of francophone African leaders to step up and make the necessary decisions. However Senegal will be the next host of the FOCAC 2021, while countries such as Mali and Burkinafaso have projected to create African Centers for Chinese studies. The University of Yaoundé II of Cameroon which is the host of one of the earliest Confucius institute in Africa have signed several MoU with Chinese University. The latest one in date was at the 2019 Forum on China-Africa Film and TV Cooperation were MoU was signed between the University of Yaounde II and Zhejiang Normal University. The July 3th-5th was the effective date were the forum took place at the Salomon Tandem Muna Foundation in Yaoundé the capital city of Cameroon, with the effective participation of many leaders and Scholars from China and Cameroon. I hosted and translated for the forum and gave a speech as African scholar as well, proposing from a balanced view of an African who have studied and worked in China, some basic steps that could speed up the China-Africa film and TV cooperation and strengthen the people to people exchanges such as the setting up of co- 
research programs between our Chinese and Cameroonian Universities in the field of Cinema, the Co-direction of Sino-Cameroonian movies as well as the active participation of Cameroonian movies in Chinese movies festivals and vice versa, the establishment of Sino-African movie festivals were experts on both sides could gather and exchange experience.

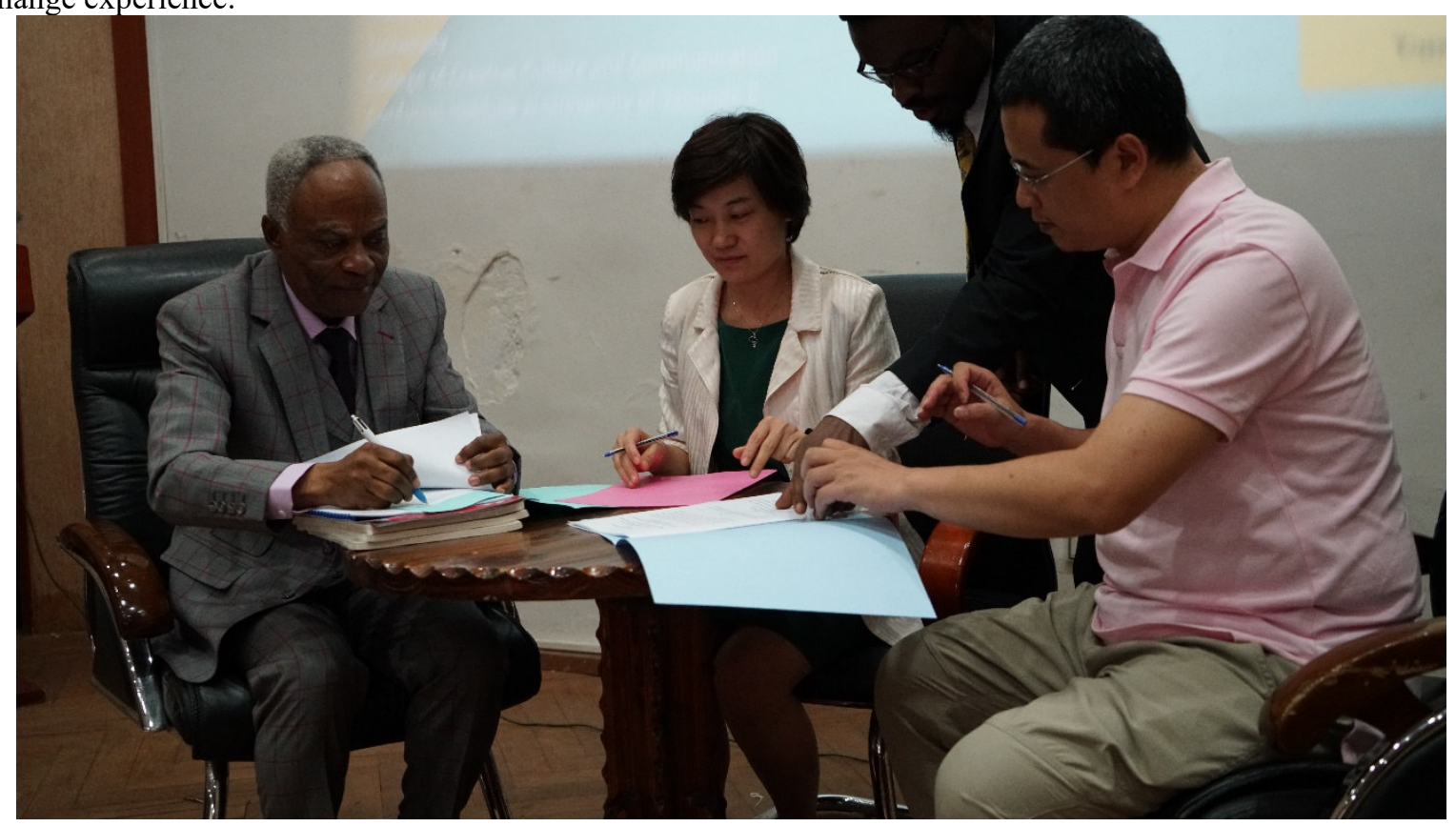

Figure6. Cooperation Agreement was signed between the University of Yaoundé II of Cameroon and Zhejiang Normal University of China

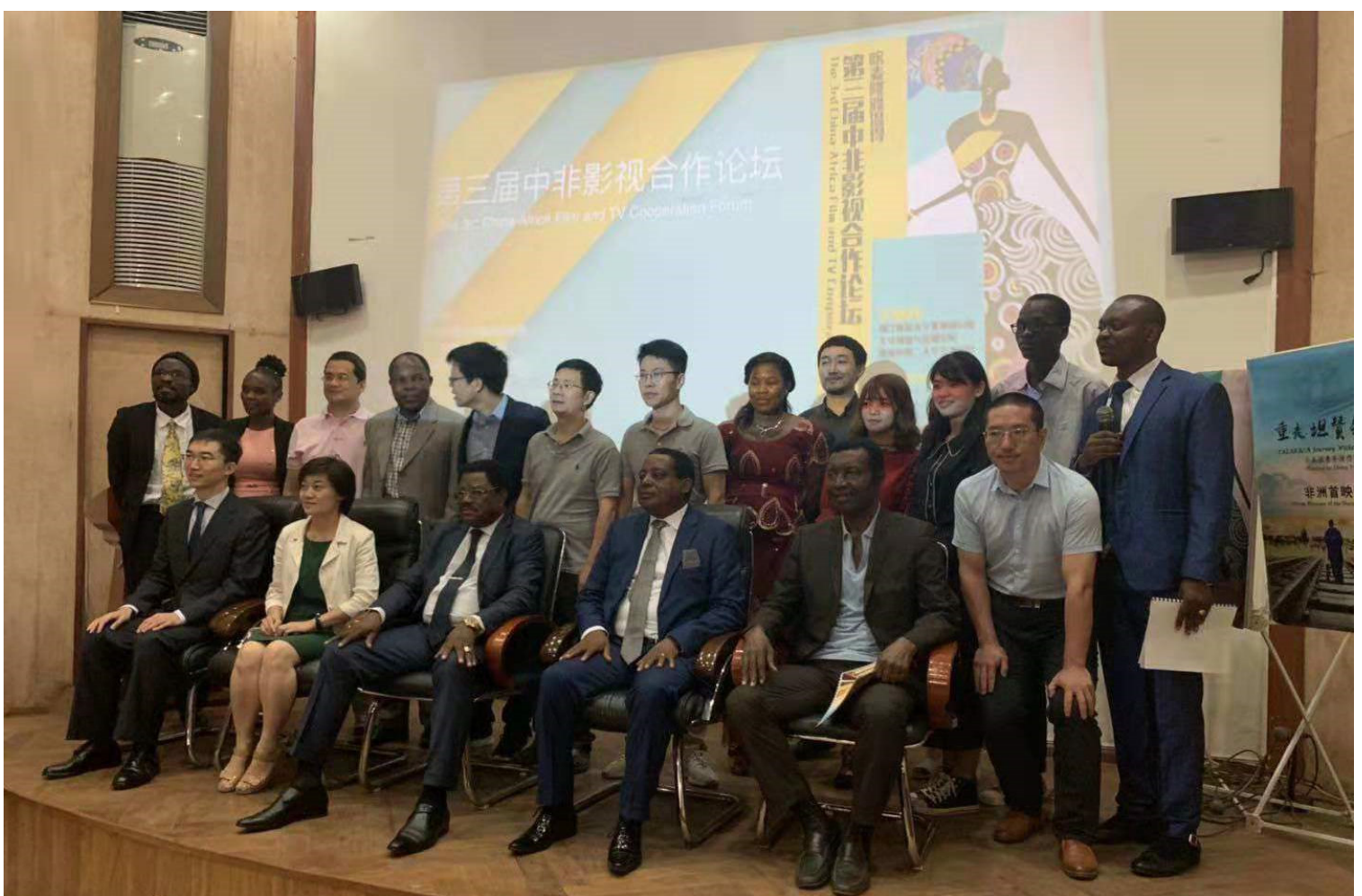

Figure7. Family photo of Chinese and African Scholars and Chinese-Cameroonian government's officials present at the forum (Author with the microphone as the official host of the forum)

Even though lagging behind on Anglophone African countries, these few examples illustrate the will of the Francophone African countries to actively step up education cooperation with China as well. 


\section{4- African Sinology: Toward a new pattern of Chinese Studies in Africa 4-1 Sinology in Western Academia}

Sinology is widely defined is Western academia as an academic discipline that focuses on the study of China primarily through Chinese thought, Chinese language, literature, Chinese culture, and history. The study of Chinese language in this definition was historically seen to be equivalent to the application of philology to China and until the 20th century was generally seen as meaning "Chinese philology" (philology is the study of literary texts as well as oral and written records mainly from historical sources; it includes the establishment of their authenticity, their original form, the determination of their meaning as well as the intersection of textual criticism, literary criticism, history, and linguistics). From the above definition, the earliest evidence shows that Western Sinology has been on existence as early as the $17^{\text {th }}$ Century. In fact, "the earliest Westerners to study the Chinese language were 16th-century Portuguese, Spanish, and Italian missionaries-all from either the Dominican Order or the Jesuits-seeking to spread Roman Catholicism among the Chinese people. An early Spanish Dominican mission in Manila operated a printing press, and between 1593 and 1607 produced four works on Catholic doctrine for the Chinese immigrant community, three in Classical Chinese and one in a mixture of Classical Chinese and vernacular Hokkien"'(Honey, 2001). But, they have been a paradigm shift in the concept of Sinology, and mostly in the $2^{\text {nd }}$ half of the $20^{\text {th }}$ Century were humanistic studies in the west witness "theory explosion"(Zhang Wanmin, 2019). Unlike traditional European Sinology, American Sinology borrowed the latest Western theoretical approaches and formed a unique feature. One of the most detailed works showing the case of Western theories applied to literary works from a Chinese perspective is that of the Chinese scholar Zhou Faxiang. In his book <Western Literary Theories and Chinese Literature $>$, he "evaluates and summarizes Western Sinologists' numerous attempts to transplant Western theory and provides references for the development of Chinese literary theories and criticism in the new historical era". Well known in the United States under the label "Chinese Studies", the new Sinology of today has broadened to embrace Chinese politics, economy, etc. Yue Dai Yun of Peking University gave a deep insight into the paradigm shift from Ancient to new Sinology when he writes: "Traditional sinology is mainly based upon the individual interest of sinologists who studied China as an isolated object. At that time, Sinology was a marginal discipline. The influence of Chinese culture was manifested mostly in the works of main-stream writers who were not sinologists such as Voltaire, Goethe, Leibnitz and Jung. 'Chinese Studies' in America after World War II which had the mission to find appropriate policies toward China also treated China as an isolated object. But the sinology since the 90's is very different from the traditional sinology of Europe and the 'Chinese Studies' in America. The new sinology emphasizes 'inter-subjectivity', 'inter-textuality' and 'inter-objectivity'. It stresses the need to do reflexive self-studies while studying the others so that we can construct each other at the same time." (Yue Dai Yun, 2002) this move has been seen by Chinese and western Scholars as a positive one, as it attempts to narrow the gap between the Western Sinology and the study of China by the Chinese themselves commonly known in Chinese academia as "GUO XUE". In fact, literally translated as "Chinese National Learning", the Chinese expression "GUO XUE" first appeared in the Chinese classic $<$ ZHOULI ZHENGYI> written by the Chinese scholar Xun Yirang at around 1899. Its original meaning clearly refers to "Imperial School", i.e. a set of Schools and institutions established by the Imperial order. The teaching contents in those institutions were referred as the “Six Arts” namely “礼(Ethics)”, “乐(Music)”, “射(Shooting)”, “御(Law)”, “书 (Books, Archives)”, “数 (Numbers, Mathematics)”(Liu Dong, 2011). It is noteworthy to indicate that the "Imperial School" have been in existence far long before the expression "GUO XUE". "GUO XUE" was just a precise nomenclature given to it at a precise period of Chinese history. the concept later evolved in meaning (sometimes called HANXUE, ZHONGUO XUE, etc.) and broadened in content and is known in today's Chinese academia to be the Chinese traditional ideological and cultural learning, it represents the quintessence of Chinese culture and embraces ancient Chinese philosophy (Taoism, Confucianism...), various school of thoughts in ancient China, history, religion (Buddhism), literature, ritual and custom, textual research (classics), ethics, traditional Chinese medicine, agriculture, mathematics, geography, politics, economy, calligraphy and painting, music, architecture, and many other aspects. In this regard, "GUO XUE" can be seen as a sort of "Chinese Sinology" with the nuance that it emphasizes on the Chinese Contribution to the world Humanities and Sciences over the course of 5000 years of Chinese history". Today's Chinese education system attaches significant importance to the field as it promotes the national cultural and ideological identity. Majors and faculties have been created in Chinese Universities to propel the studies and research on that area of study. For instance, in 2005, the Chinese people University established national colleges; In 2009, Tsinghua University established the sinology research institute, In 2006, Guangming daily set up a special edition of sinology and published the article "sinology is A discipline". However, they have been debates over the academic status of sinology, whether from West or East, scholars still find it difficult to classify Sinology within a precise field of Linguistics, Social Sciences or Humanities given lack of an independent and consistent theory, as well as a proper socio-scientific methodology. Just as summed up in this article <Is Sinology a Science?> of Hans Kuijper: "I take 'science' to mean (the search for) systematized knowledge, that is to say, knowledge organized in conformity with generally accepted principles and methods. A scientist seeks, in a disciplined way, orderliness in the object of his study. He has a theory: not a doctrine but an 
imaginative construction suggested by the results of critical and exhaustive investigation devised to guide, or direct, his research and understanding. A theory, rather than being a dispensable luxury or unnecessary encumbrance to empirical research, provides a way of seeing and a tool for investigation; sinologists are to be dismissed as pseudo-scientists because they do not command a Sinological theory, a fact they religiously keep from outsiders. The foundations and philosophy of sinology have not been written yet; The Sinologist is a toucheà-tout sans profondeur, a jack-of-all-trades but a master of none." (Hans, 2000)The objet? The method? The theory? No matter what, we cannot deny that Sinology has provided the west with a better understanding of China and has strengthened the relationship between East and West, but most importantly is much needed in today's China opening up and reforms. Especially when we take into account projects such as one belt one road, AIIB, etc. monitored by China but where cooperation with the world is a must.

\subsection{Afrisinology: Concept proposal for a Genuine African Sinology}

The dynamics of the changing global geopolitics have driven China and African Countries closer at this particular time of the world development history. As Africa is entering a new era of relationship with the world, it is the right time to re-design theoretical foundations and practical frameworks that will re-orient its international cooperation and guide its strategic partnerships. In that regard, China as the current biggest trading partner of Africa and most important investors of the continent is with no doubt a quite important (and perhaps the most important at this time) object of study. China's Politics, Economics, Cultures, Literary, Languages, Religions, and even History and Geography should be closely studied in the African education curriculum, but most importantly like the West, Africa should have its own appraisal of China. From a theoretical basis to a proper methodology, from institutionalized frameworks to government policies, an epistemic assessment of China by the African Academia is of urgent need. African academic institutions have to host research programs and subject disciplines that focus on the most urgent China-Africa current affairs while taking into account the social-cultural and historical particularities of China. And such programs should be led by African scholars, mainly those who have experienced China. In other words, a true African Sinology or "Afrisinology" has to take place in African academia, a sort of Africa-centered study of China that fulfills traditional discipline criteria. "Afrisinology" as a Genuine African Sinology must use socio-scientific methods to critically examine and investigate its main object (China), understand the Chinese spirit, by all means, draw the benefits in relation to the core interests of African people. "Afrisinology", the African study of China must answer the ongoing interrogations on the China-Africa ambiguous relations where many still wonder whether China is exploiting Africa. These answers must not be brought neither by Eastern nor by Western scholars, but by the "Africa Experts of China", namely the "Afrisinologists" whose ultimate goal is to use theories to affect the minds, use methods to anticipate on decisions making. However, we are fully aware that a genuine African Sinology will not happen without challenges, as Western and Chinese Sinology themselves remain confronted with various disciplines criteria's challenges. The surest way to embarrass a sinologist is to inquire what variables, constants and parameters he uses, and how (strongly) they are interrelated; what postulates, or assumptions, his readings are built upon; how he operates to derive his conclusions; where his pen-products progress from meticulous description to analysis, that is to say, sinological analysis; what classification rules he follows regarding the objects within his domain; or what problems he considers to be fundamental in his profession. The foundations and philosophy of sinology have not been written yet; it would even appear that sinologists, much to their disadvantage, are not interested in the foundations and philosophy of science at all. We are still waiting for the Principia Sinologica. (Hans, 2000)

\section{Conclusion}

As the world is undergoing a geostrategic rebalancing of power with the rise of China and the developing world, it is important that ever for the African academia to reinvent its own study of China, especially the study of the country's attitude to tackle geopolitical challenges and its dynamism to path the way to a peaceful and prosperous society. Such a "Chinese Spirit" should be thoroughly investigated via an authentic African Sinology or "Afrisinology" aiming at enhancing African people understanding of China's sociocultural development principles with regards to Africa's development goals. For, digging the cornerstone of the Chinese model may be relevant for the striving developing African economies. "Afrisinology" should use theories to affect the minds, use methods to anticipate decisions making in Africa's relationship with China. In brief, further up the China-Africa Education cooperation and knowledge sharing is the lever that will propel the China-Africa dream of co-development, coprosperity and shared future to new highs.

\section{References}

Kenneth King (2019). China-Africa Education Cooperation: From FOCAC to Belt and Road. ECNU Review of Education, 1-14.

Ministry of Commerce People's Republic of China, Statistics on China-Africa Trade in 2018, January 26, 2019 09:52 
http://english.mofcom.gov.cn/article/statistic/lanmubb/AsiaAfrica/201901/20190102831255.shtml

Suzhou (2017). Number of Chinese immigrants in Africa rapidly increasing. China Daily | 2017-01-14 07:48. https://www.chinadaily.com.cn/world/2017-01/14/content_27952426.htm

Jenni Marsh. "The African migrants giving up on the Chinese dream". CNN, Updated 0633 GMT (1433 HKT) September 26, 2016. https://edition.cnn.com/2016/06/26/asia/africans-leaving-guangzhou-china/

Zhuang Pinghui (2014). Guangzhou clarifies size of African community amid fears over Ebola virus. South China Morning Post. Published: 4:34am, 1014. https://www.scmp.com/news/china/article/1629415/guangzhou-clarifies-size-african-community-amidfears-over-ebola-virus

Cambridge, James; Thompson, J. (2004). Internationalism and globalization as contexts for international Education. Journal of Comparative and International Education, 161-175.

Hayden, Mary; McIntosh, S. (2018). International education: the transformative potential of experiential learning. Oxford Review of Education, 403-413.

Vanessa R. Sperduti (2017). Internationalization as Westernization in Higher Education. Comparative \& International Education 9, 9-12.

Alden, C., \& Large, D. (2019). New directions in Africa-China studies. London: Routledge.

Steven W. Mosher (2012). Confucius Institutes: China carries out a 'Long March' through our Universities, Human Events. https://humanevents.com/2012/09/07/confucius-institutes-how-china-iscarrying-out-a-long-march-through-our-universities-and-brainwashing-the-next-generation/

James F. Paradise (2009), China and International Harmony: The Role of Confucius Institutes in Bolstering Beijing's Soft Power, Asian Survey (49.4), 648-649.

Fabrice de Pierrebourg, Michel Juneau-Katsuya (2009). Nest of Spies: the starting truth about foreign agents at work within Canada's borders. HarperCollins Canada, 160-162.

Qu Yingpu, Zhao Huanxin and Cheng Ying (2012), Confucius Institutes go beyond borders, China Daily 201212-02.

Japanese university apologizes for calling Confucius Institute spy agency, People's Daily, 12 June 2010.

Jessica Shephard (2007), "Not a propaganda tool": China's Confucius Institutes are proliferating at UK universities, but are they cultural or political bodies? The Guardian 5 November 2007.

Justin Norrie (2011), Confucius says Schools in, but don't mention democracy, The Sydney Morning Herald, 20 February 2011.

Alexander Kuenzle and Ting Song (2012), Chinese culture centres spark propaganda fears. swissinfo.

Chang, Liu (2010). "No need to fuss over Confucius Institutes". China Daily. Xinhua. Retrieved 14 August 2010.

Steven W. Mosher (2012). Confucius Institutes: China Carries out a 'Long March' through our Universities, Human Events, 7 September 2012. https://humanevents.com/2012/09/07/confucius-instituteshow-china-is-carrying-out-a-long-march-through-our-universities-and-brainwashing-the-next-generation/

Liu Hongwu (2019). Introduction to African Studies. People's Publishing House, 36-37.

People's Daily April 26, 2005. China, Egypt sign agreement on establishing Chinese university. http://en.people.cn/200504/26/eng20050426_182801.html

Yurou (2019). Interview: Egyptian Chinese University center for promoting Chinese culture in Egypt: university chief. Xinhua News| 2019-08-21 |http://www.xinhuanet.com/english/2019-08/21/c 138324503.htm

$\mathrm{Mu}$ Xuequan (2018). Center for Chinese Studies opens in Tanzania. Xinhua News. http://www.xinhuanet.com/english/2018-05/16/c_137181360.htm

Honey, David B. (2001). Incense at the Altar: Pioneering Sinologists and the Development of Classical Chinese Philology. New Haven: American Oriental Society, 6.

Zhang Wanmin (2019). Western Theory and the Study of Classical Chinese Literature in North America. Contemporary Social Science, 99.

Yue Dai Yun (2002), A New Trend in Sinology and Its Possible Effect on Comparative Literature. Comparative Literature: East \& West (vol4), 1-2.

Liu Dong (2011). National Learning (Gouxue): Six Perspectives and Six Definitions. China Perspectives, 46-54.

"GOU XUE": Historical Changes of Definitions and Thoughts. Journal of HuBei TV University December (Vol 27), 96.

Hans Kuijper (2000). Is Sinology A Science? China Report Volume (36), 331-354. 